\title{
TOTAL SURGICAL RESECTION OF SOLITARY BONE PLASMACYTOMA OF THE SPINAL COLUMN
}

\author{
Nebojša Stojanović1,2, Aleksandar Kostić1,2, Radisav Mitić1,2, Miša Radisavljević1,2, \\ Luka Berilažićí,
}

\begin{abstract}
Solitary plasmacytomas are a hematological disorder. They can take the form of solitary bone plasmacytoma (SBP) and the form of solitary extramedular plasmacytoma (SEP). These types tend to become multiple myeloma (MM). Treatment is predominately hematologic and radiation therapy. In most cases, SBP is detected after the destruction of the vertebrae and the occurrence of neurological deficits. It is very important to indicate the appropriate and timely surgical approach before applying further therapeutic procedures.

Eight patients in whom it was decided to apply surgical procedure of total tumor resection prior to the application of chemo- and radiation therapy were subjected to analysis. The surgical approach involved the complete removal of altered vertebral bodies with anterior and posterior reconstruction of the spinal column. The primary preoperative and post-operative neurological status was monitored.

Removing the corpus which compromises the width of the spinal canal and the removal of the spinal cord pressure allows neurological recovery or the prevention of severe neurological damage resulting from the destabilization of the spinal column. In all cases there was significant neurological improvement. In addition, in cases of SBP of vertebrae, long-term remission or healing is often achieved.

Complete removal of solitary plasmacytomes of the vertebrae allows the patient to actively continue with further treatment and the prevention of severe neurological damage. A complete 3D reconstruction of the spinal column and the achievement of its mechanical stability is a prerequisite for achieving neurological stability. A timely surgical intervention is conditioned by quality preoperative diagnostic approach and early detection.
\end{abstract}

Acta Medica Medianae 2019;58(3):147-152.

Key words: solitary bone plasmacytoma, spine, multiple myeloma

\footnotetext{
${ }^{1}$ Clinic of Neurosurgery, Clinical Center Niš, Serbia

2University of Niš, Faculty of Medicine, Niš, Serbia
}

Contact: Nebojša Stojanović

Blvd dr Zoran Djindjić 81, 18000 Niš, Serbia

E-mail: nesamed59@gmail.com

\section{Introduction}

Solitary plasmacytomas (SP) are a rare condition of plasma cells and comprise $5 \%$ of all plasma cell neoplasms (1-4). There are two entities depending on the localization: solitary bone plasmacytoma (SBP) and extramedullary plasmacytoma (EMP) (5). They are basically defined as a proliferation of monoclonal plasma cells without evidence of significant infiltration of the bone marrow with plasma cells. The spinal column is the most common site of the solitary plasmacytoma.

According to the new criteria of the International Myeloma Working Group (IMWG), the patient may have solitary bone myeloma if there is no $M$ protein in the serum or in the urine (a small amount of $\mathrm{M}$ protein may be present). In addition, it is necessary to define the existence of only one area of bone destruction associated with the presence of plasma cells by means of the MRI finding of the spine and pelvis (6). Recommendations for the treatment of these changes are generally obtained from retrospective studies due to the small number of patients observed in the studies $(1,4,7,8)$. The most common approach to treating these changes is the application of radiation therapy (RT) to which plasmacytoma is highly sensitive. However, bone plasmacytoma is known to progress and grow into multiple myeloma (MM) despite the applied radiotherapies (9). There is no information in the literature on the optimum RT for SP. Most centers use between 30 and $50 \mathrm{~Gy}$ or more to treat $\operatorname{SP}(2,10,11)$. 
In the latest solitary bone plasmacytoma (SBP) treatment protocols, the British Society for Hematology (12) recommends surgical removal of SBP, followed by radiochemotherapy. In addition, a large number of papers suggest that surgical intervention is useful for eliminating tumors, correcting pathological fractures and preventing neurological deficits (12). A number of papers have indicated that surgery contributed to better local control and survival length (3). The Guidelines from the National Comprehensive Cancer Network (NCCN) (NCCN, Version 4 , 2014) recommend the use of surgery or a combination of surgery and radiotherapy.

\section{Materials and methods}

Eight patients were subjected to the surgical treatment for solitary plasmacytoma of the spinal column vertebrae in the period from 2014 to 2018. Surgeries were performed at the Neurosurgical Clinic of the Clinical Center in Niš. The localization of solitary plasmacytomas was as follows: two were found in the cervical spine, 4 in the craniocervical passage and 2 in the thoracic part of the spine.

The selection of patients was done after the performed MRI of the spine due to the development of neurological deficits of varying degrees. The occurrence of neurological damage was on average related to a short period before MRI or after innocuous injuries.

In all patients, complete blood chemistry testing was carried out after the discovery of solitary, destructive changes on the vertebral bodies of the spinal column. Because of the suspicion of plasmacytoma, based on the MRI features, the level of M protein in the urine and blood was measured and MSCT of lungs or abdomen and RT of the pelvis and the skull were performed in all patients. principles:

The surgical approach consisted of 4 basic

- $1^{\text {st }}$ surgical principle: the principle of complete removal of the pathological process and replacement of the bone structures by auto- or allomaterial

- $2^{\text {nd }}$ surgical principle: enabling complete decompression of the nerve elements in the affected part of the spinal canal
- $3^{\text {rd }}$ surgical principle: achieving adequate correction of the cervicothoracic curve while preserving the cervical lordosis

- $4^{\text {th }}$ surgical principle: good stabilization without the possibility of postoperative static disorders of the spine

By applying this surgical technique, 3D reconstruction of the spinal column was obtained, which enabled complete mechanical and then neurological stability.

\section{Results}

Due to the localization of vertebral destruction, one of the neurological deficits was registered in all patients. Preoperative muscular strength and its immediate postoperative recovery score after 2 months were observed - BMRC (Table 1).

Surgical intervention implied the complete removal of the spinal column vertebra that was affected by the process. The applied technique of complete reconstruction of the spinal column had its own surgical requirements depending on the localization of destruction of the vertebral body.

In the cervical spine area, the anterior approach was first applied to completely remove the vertebral body altered by the destruction with releasing of the spinal canal and pressure on the spinal cord and replacing the removed vertebral body with an artificial corpus. For stability reasons, the anterior stabilization was always done with a titanium plate. This was followed by applying the posterior approach and stabilization of the posterior bone systems, in order to achieve the necessary stability of the spinal column (Figure 1).

In the cervicothoracic area, two approaches were applied due to the complex anatomical localization:

1. Posterior bilateral approach with resection of the ribs and lateral-posterior bilateral removal of the corpus, and then inserting an artificial corpus with the application of the posterior cervicothoracic stabilization and

2. Combined posterior approach with removal of the corpus and anterior stabilization, followed by the use of the posterior cervicothoracic stabilization (Figure 2).

Table 1. Degrade of damage of most affected muscle group before and two months after surgery

\begin{tabular}{|lcccccccc||}
\hline Localization SBP & C3 & C6 & Th1 & Th2 & Th6 & Th7 & Th8 & Th8 \\
\hline $\begin{array}{l}\text { MSG before } \\
\text { surgery }\end{array}$ & 3 & 2 & 3 & 3 & 4 & 3 & 3 & 4 \\
$\begin{array}{l}\text { MSG two months after } \\
\text { surgery }\end{array}$ & 5 & 4 & 5 & 5 & 5 & 4 & 5 & 5 \\
\hline
\end{tabular}

*Muscular Strength Graded (MSG) according to the Royal Medical Research Council of Great Britain 


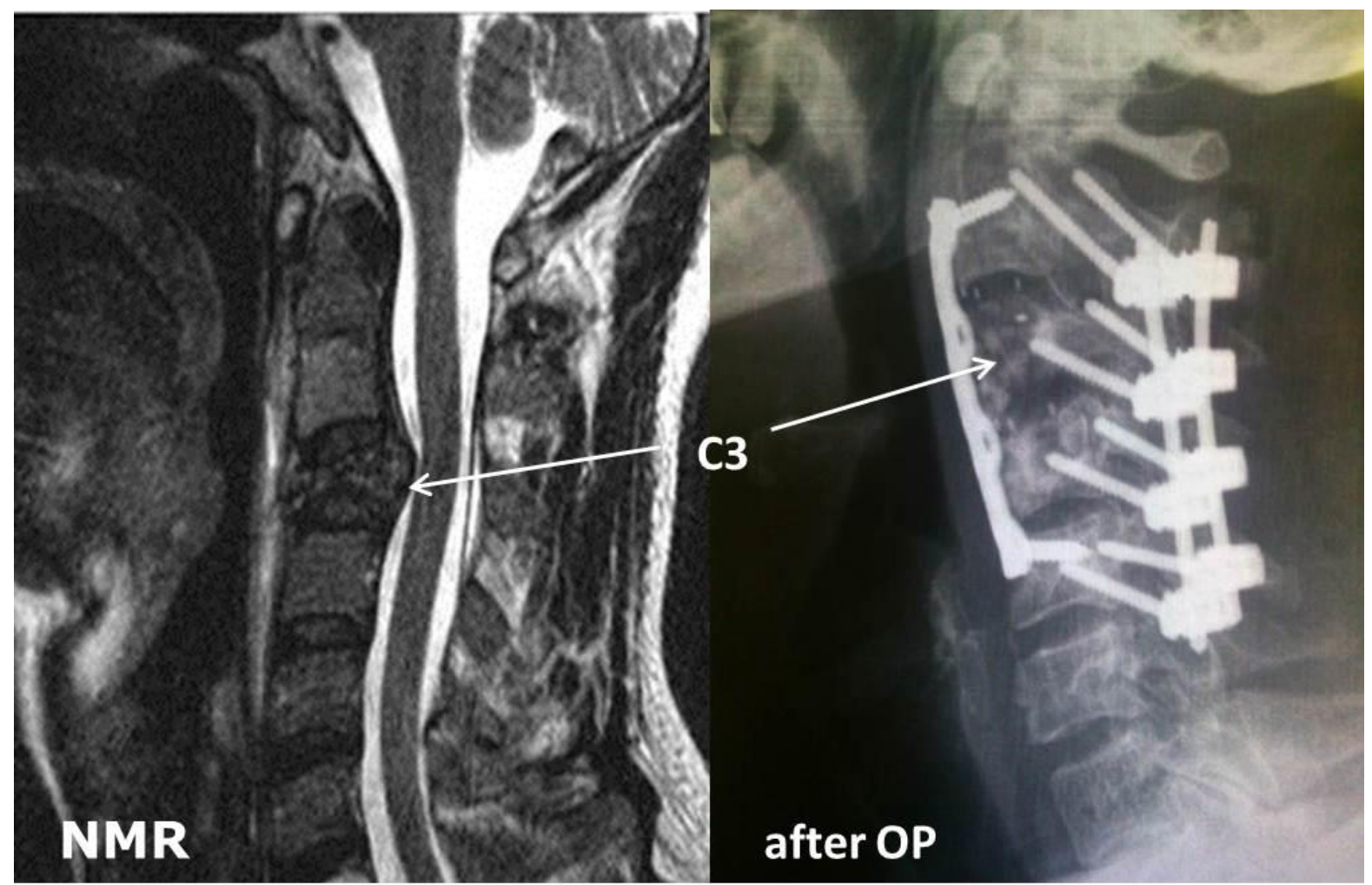

Figure 1. Reconstructive surgery of the cervical spine

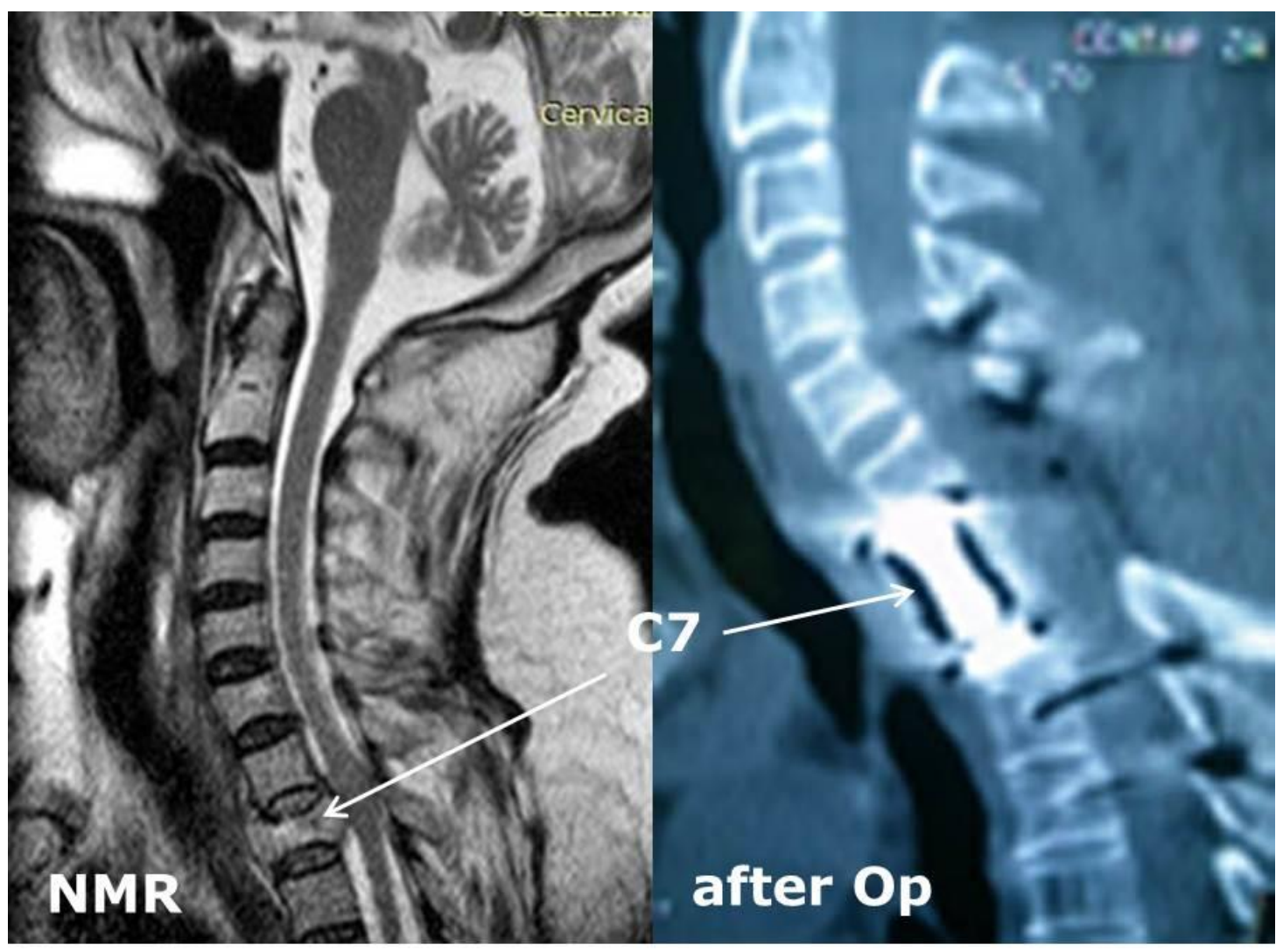

Figure 2. Reconstructive surgery of the cervicothorascic segment of the spine 


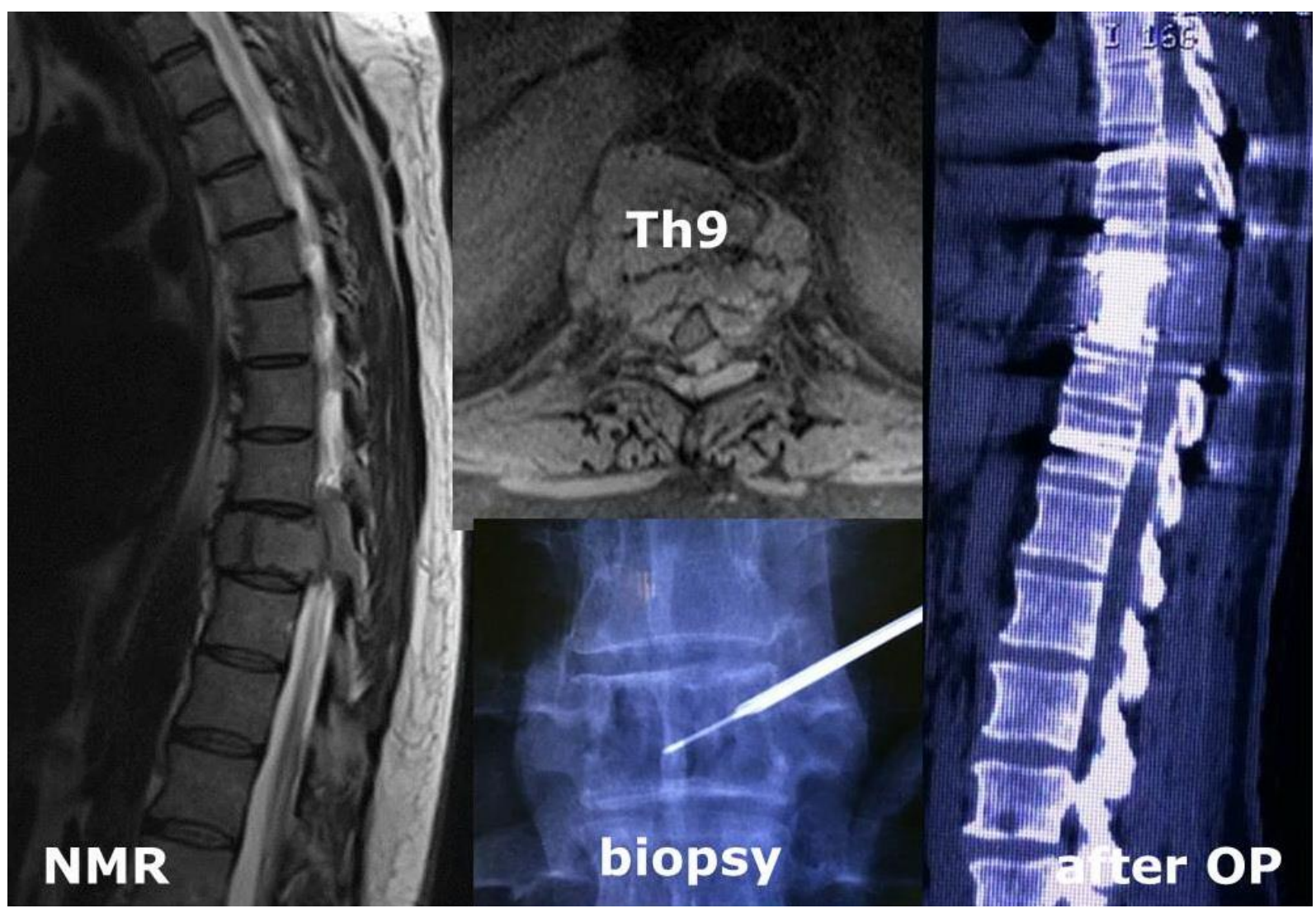

Figure 3. Reconstructive surgery of the thoracic segment of the spine

In the thoracic part of the spinal column, a lateral approach was applied through the thoracic duct, with resection of the rib and collapse of the left lung. The removal of the corpus was complete with the implantation of the artificial corpus. This was always followed by the posterior thoracic transpeduncular stabilization (Figure 3).

\section{Discussion}

The application of the principle of complete surgical removal of solitary bone plasmacytoma has been emphasized in many papers $(12,13)$. The length of survival and the disease-free period are considerably longer. Due to the lack of complete multicentric studies and inadequate post-operative control of the patient, data on the length of survival are not unique $(3,13)$. In addition, the surgical techniques used to remove the tumor processes have not been harmonized (14). The radical elimination of solitary plasmacytomas of the spinal column can significantly affect the prolongation of the remission of the disease (15).

The question arises of the need for a combined procedure, which would involve the use of radiotherapy, and even chemotherapy, after surgery. The protocols have not been clearly harmonized.

Within this small series, it is not possible to give clear and accurate guidelines for the treatment of solitary bone plasmacytoma. Still, there are data which should be taken into consideration, namely, that radiation therapy was not used in 2 patients after surgery; in 2 patients only radiation therapy was used, and in 4 both radiation therapy and chemotherapy were used.

In patients undergoing surgery alone, chemotherapy was introduced after 14 and 18 months due to the deterioration of the general biohumoral status and the increase in the level of $M$ protein in the urine. Subsequently, due to the progression of the disease towards multiple myeloma (MM) disease, bone marrow transplantation was also performed in one of the patients.

In the group of patients in whom only radiation therapy was used, 2 patients are still without progression of the disease, and in 2 patients an additional chemotherapeutic approach was applied.

In the group of patients receiving radiochemotherapy, one patient was in remission and under control, whereas no data was available for the other patient (after regular surgical controls and general well-being, he did not show up for his follow-up appointments).

From this small analysis of the treatment outcomes, the application of radiotherapy may also be suggested although no high levels of $M$ proteins in the blood and urine were recorded after the surgical removal of solitary bone plasmacytomas. Chemotherapy should already be considered as well in patients with $M$ protein levels at a $20 \mathrm{~g} / \mathrm{l}$ limit. There is 
also an opinion that the approach for treating solitary bone plasmacytomas should be the same as in multiple myeloma $(16,17)$.

\section{Conclusion}

By using partial reduction surgical techniques, which are directed only to the decompression of the spinal canal, most of the solitary bone plasmacytoma remain, which extremely increases the risk of further progression of the disease despite the application of other treatment procedures. Likewise, partial reduction of the tumor does not lead to the achie- vement of the mechanics of stability of the spinal column, and patients are often bed-ridden.

Complete surgical removal of solitary plasmacytomas of vertebral bodies of the spinal column results in a very rapid neurological recovery. With the application of the $3 \mathrm{D}$ reconstruction technique and complete implementation of the artificial corpus, and by achieving the necessary mechanical stability of the spinal column, the patient can be fully involved in further treatment procedures. The patient becomes active without the risk of developing neurological diseases.

\section{References}

1. Knowling MA, Harwood AR, Bergsagel DE. Comparison of extramedullary plasmacytomas with solitary and multiple plasma cell tumors of bone. J Clin Oncol 1983; 1(4):255-62. [CrossRef] [PubMed]

2. Dimopoulos MA, Hamilos G. Solitary bone plasmacytoma and extramedullary plasmacytoma. Curr Treat Option Oncol 2002; 3(3):255-9. [CrossRef] [PubMed]

3. Ozsahin $M$, Tsang RW, Poortmans $P$, Belkacémi $Y$, Bolla M, Dinçbas FO, et al. Outcomes and patterns of failure in solitary plasmacytoma: a multicenter rare cancer network study of 258 patients. Int J Radiat Oncol Biol Phys 2006; 64(1):210-7.

[CrossRef] [PubMed]

4. Sun WJ, Zhang JJ, An N, Shen M, Huang ZX, Li X. Clinical analysis of 40 multiple myeloma patients with extramedullary plasmacytoma of the head. J Int Med Res 2016; 44(6):1462-73. [CrossRef] [PubMed]

5. Galieni P, Cavo M, Avvisati G, Pulsoni A, Falbo R, Bonelli MA, et al. Solitary plasmacytoma of bone and extramedullary plasmacytoma: two different entities? Ann Oncol 1995; 6(7):687-91. [PubMed]

6. Criteria for the classification of monoclonal gammopathies, multiple myeloma and related disorders: a report of the International Myeloma Working Group. $\mathrm{Br}$ ] Haematol 2003; 121(5):749-57. [CrossRef] [PubMed]

7. Brinch L, Hannisdal E, Abrahamsen AF, Kvaløy S, Langholm R. Extramedullary plasmacytomas and solitary plasma cell tumours of bone. Eur J Haematol 1990; 44(2):132-5. [CrossRef] [PubMed]

8. Shih LY, Dunn P, Leung WM, Chen WJ, Wang PN. Localised plasmacytomas in Taiwan: comparison between extramedullary plasmacytoma and solitary plasmacytoma of bone. Br J Cancer 1995, 71(1):128-33. [CrossRef] [PubMed]

9. Dimopoulos MA, Moulopoulos LA, Maniatis A, Alexanian R. Solitary plasmacytoma of bone and asymptomatic multiple myeloma. Blood 2000; 96(6):203744. [CrossRef] [PubMed]
10. Bolek TW, Marcus RB Jr, Mendenhall NP. Solitary plasmacytoma of bone and soft tissue. Int J Radiat Oncol Biol Phys 1996; 36(2):329-33. [CrossRef] [PubMed]

11. Knobel D, Zouhair A, Tsang RW, Poortmans P, Belkacémi $Y$, Bolla $M$, et al. Prognostic factors in solitary plasmacytoma of the bone: a multicenter Rare Cancer Network study. BMC Cancer 2006; 6:118. [CrossRef] [PubMed]

12. Soutar R, Lucraft $H$, Jackson G, Reece A, Bird J, Low $\mathrm{E}$, et al. Guidelines on the diagnosis and management of solitary plasmacytoma of bone and solitary extramedullary plasmacytoma. $\mathrm{Br}$ J Haematol 2004; 124 (6):717-26. [CrossRef] [PubMed]

13. Li QW, Niu SQ, Wang HY, Ge Wen, Li YY, Xia YF, et al. Radiotherapy alone is associated with improved outcomes over surgery in the management of solitary plasmacytoma. Asian Pac J Cancer Prev 2015; 16(9): 3741-45. [CrossRef] [PubMed]

14. Bachar G, Goldstein D, Brown D, Tsang R, Lockwood G, Perez-Ordonez B, et al. Solitary extramedullary plasmacytoma of the head and neck-long term outcome analysis of 68 cases. Head Neck 2008; 30(8): 1012-9. [CrossRef] [PubMed]

15. Bataille R, Sany J. Solitary myeloma: clinical and prognostic features of a review of 114 cases. Cancer 1981; 48(3):845-51. [CrossRef] [PubMed]

16. Dores GM, Landgren O, McGlynn KA, Curtis RE, Linet MS, Devesa SS. Plasmacytoma of bone, extramedullary plasmacytoma, and multiple myeloma: incidence and survival in the United States, 1992-2004. $\mathrm{Br}$ ] Haematol 2008; 144(1):86-94. [PubMed]

17. Katodritou E, Terpos E, Symeonidis AS, Pouli A, Kelaidi C, Kyrtsonis MC, et al. Clinical features, outcome, and prognostic factors for survival and evolution to multiple myeloma of solitary plasmacytomas: A report of the Greek myeloma study group in 97 patients. Am J Hematol 2014; 89(8):803-8. [CrossRef] [PubMed] 


\title{
TOTALNA HIRURŠKA RESEKCIJA SOLITARNOG PLAZMOCITOMA U VRATNOM I TORAKALNOM DELU KIČMENOG STUBA - ANALIZA SLUČAJEVA
}

\author{
Nebojša Stojanović1,2, Aleksandar Kostić1,2, Radisav Mitić1,2, Miša Radisavljević1,2, \\ Luka Berilažić1,2
}

${ }^{1}$ Klinika za neurohirurgiju, Klinički centar Niš, Niš, Srbija

2Univerzitet u Nišu, Medicinski fakultet, Niš, Srbija

Kontakt: Nebojša Stojanović

Bulevar dr Zorana Đinđića 81, 18000 Niš, Srbija

E-mail: nesamed59@gmail.com

Solitarni plazmocitomi su hematološko oboljenje, koje može poprimiti formu solitarnih koštanih plazmocitoma (SBP) i formu solitarnih ekstramedularnih plazmocitoma (SEP). Ove vrste imaju tendenciju prerastanja u multiple mijelome (MM).Pristup lečenju je, dominanto, hematološkom i zračnom terpijom. U većini sličajeva do otkrivanja SBP dolazi nakon destrukcije kičmenih prišljenova i pojave neuroloških deficita. Veoma je značajno pravovremeno indikovati odgovarajući hirurški pristup pre primene daljih terapijskih procedura.

Analiziranju je podvrgnuto 8 bolesnika kod kojih je odlučeno da se pristupi hirurškoj proceduri totalne resekcije tumora pre primene hemioterapije i zračne terpije. Hirurški pristup je podrazumevao kompletno uklanjanje izmenjenih kičmenih pršljenskih tela sa prednjom i zadnjom rekonstukcijom kičmenog stuba. Praćeni su primarni preoperativni i post operativni neurološki statusi.

Uklanjanjem korpusa, kojim je kompromitovana širina kičmenog kanala i uklanjanjem pritiska na kičmenu moždinu, omogućuje se neurološki oporavak ili prevencija teških neuroloških oštećenja zbog destabilizacije kičmenog stuba. U svim slučajevima, došlo je do značajnog neurološkog poboljšanja. Pored toga, u slučajevima solitarnih plazmocitoma pršljenskih tela, često dolazi do postizanja dugovremenih remisija i/ili izlečenja.

Kompletno uklanjanje solitarnih plazmocitoma kičmenih pršljenova omogućava da bolesnik aktivno nastavi sa daljim lečenjem uz preventiranje teških neuroloških oštećenja. Kompletna 3D rekonstrukcija kičmenog stuba i postizanje njegove mehančke stabilnosti bitan je preduslov za postizanje i neurološke stabilnosti. Pravovremena hirurška intervencija je uslovljena i kvalitetnim preoperativnim dijagnostičkim pristupom i ranim otkrivanjem.

Acta Medica Medianae 2019;58(3):147-152.

Ključne reči: solitarni koštani plazmocitom, kičma, multipli mijelom 